\title{
Malathion and Propoxur Resistance in Turkish Populations of the Anopheles maculipennis Meigen (Diptera: Culicidae) and Relation to the Insensitive Acetylcholinesterase
}

Türkiye Anopheles maculipennis Meigen (Diptera: Culicidae) Populasyonlarında Malathion

ve Propoxur Direnci ve Duyarsız Asetilkolinesteraz ile İlişkisi

\section{Muhammet Mustafa Akıner}

Department of Biology, Recep Tayyip Erdoğan University, Rize, Turkey

\section{ABSTRACT}

Objective: The objective of this study was to evaluate insecticide resistance related to acetylcholinesterase (AChE) sensitivity and annual changes in An. maculipennis from six different populations.

Methods: Larvae and adult samples of An. maculipennis were collected from six different localities (Birecik, Beysehir, Cankiri, Avariz, Tatarkoy, Derekoy) in Turkey. Insecticide susceptibility against malathion and propoxur was determined. AChE and insensitive AChE levels were measured individually.

Results: All Anopheles maculipennis population mortality rates were placed in the suspected resistance category for malathion and propoxur in 2007. While Thrace region populations (Avariz, Tatarkoy, Derekoy) were placed in the surveillance category in 2008, the Birecik, Beysehir, and Cankiri populations were identified in the resistance category. According to the biochemical assay, AChE inhibition rates were high in 2007 and decreased in 2008, except in Derekoy.

Conclusion: Our results revealed that insecticide resistance against malathion and propoxur increased from 2007 to 2008 . Biochemical assay results showed that the AChE insensitivity for 2 test years and insensitive AChE frequency had increased annually. Our results also showed that extensive usage of organophosphate and carbamate for pest control in agriculture is a key factor for malathion and propoxur resistance in all tested populations rather than direct usage of mosquito control.

(Turkiye Parazitol Derg 2014; 38: 111-5)

Key Words: Anopheles maculipennis, insecticide resistance, insensitive acetylcholinesterase, malathion, propoxur

Received: 12.10 .2013

Accepted: 25.12 .2013

\section{ÖZET}

Amaç: Bu çalışmanın amacı, altı farklı Anopheles maculipennis populasyonunda insektisit direnci ile bağlantılı olarak asetilkolinesteraz (AChE) duyarlılığının ve yıllık değişiminin belirlenmesidir.

Yöntemler: Larva ve ergin Anopheles maculipennis örnekleri Türkiye'nin altı farklı noktasından (Birecik, Beyşehir, Çankırı, Avarız, Tatarköy ve Dereköy) toplanmıştır. Malathion ve propoxur'a karşı insektisit duyarlılığı tanımlanmıştır. AChE ve duyarsız AChE seviyeleri bireysel olarak ölçülmüştür.

Bulgular: 2007 yılında malathion ve propoxur için tüm Anopheles maculipennis populasyonlarının ölüm oranları şüpheli direnç kategorisinde yer almıştır. 2008 yılında Trakya bölgesi populasyonları (Avarız, Tatarköy, Dereköy) şüpheli direnç kategorisinde yer alırken, Birecik, Beyşehir ve Çankırı populasyonları dirençli kategoride belirlenmiştir. Biyokimyasal testlerin sonuçlarına gore AChE inhibisyon oranları 2007 yılında yüksek değerdedir ve 2008 yılında Dereköy soyu hariç azalmıştır.

Address for Correspondence / Yazışma Adresi: Dr. Muhammet Mustafa Akıner, Department of Biology, Recep Tayyip Erdoğan University, Rize, Turkey. Phone: +90 4642236126 E-mail: akiner.m@gmail.com DOI:10.5152/tpd.2014.3388

(C) Copyright 2014 Turkish Society for Parasitology - Available online at www.tparazitolderg.org

OTelif hakkı 2014 Türkiye Parazitoloji Derneği - Makale metnine www.tparazitolderg.org web sayfasından ulaşılabilir. 
Sonuç: Bizim sonuçlarımız malathion ve propoxura karşı insektisit direncinin 2007 yılından 2008'e arttığını ortaya çıkarmıştır. Biyokimyasal deneylerin sonuçları her iki yılda da asetilkolinesteraz duyarsızlığını ve duyarsız asetilkolinesteraz frekansının yıldan yıla arttığını göstermiştir. Bizim sonuçlarımız aynı zamanda tüm çalışılan populasyonlarda malathion ve propoxur direnci için tarımda zararlı kontrolünde yoğun olarak kullanılan organofosfat ve karbamatların, direkt sivrisinek kontrolünde kullanılanlardan daha önemli anahtar faktör olduğunu göstermiştir. (Turkiye Parazitol Derg 2014; 38: 111-5)

Anahtar Sözcükler: Anopheles maculipennis, insektisit direnci, duyarsız asetilkolinesteraz, malathion, propoxur

Geliş Tarihi: 12.10.2013

Kabul Tarihi: 25.12.2013

\section{INTRODUCTION}

Anopheles maculipennis complex is the vector of malaria in Europe and the Middle East throughout history, and malaria is still a serious problem in the Middle East and Minor Asia (1). An. maculipennis complex comprises 12 palearctic members; three of its members (An. atroparvus, An. labranchiae, and An. sacharovi) are known to be efficient vectors of malaria in the palearctic (2-5). Currently, there are 56 recognized species of mosquito, and An. sacharovi, An. Superpictus, and An. maculipennis are the most important malaria vectors in Turkey $(6,7)$.

Anopheles sacharovi is the main vector in Turkey and has widespread distribution in many parts of our country but is generally found in mixed populations with An. maculipennis and An. melanoon (8). Insecticides have been widely used since the late 1960s, and numerous cases of resistance have been determined in insects. Resistance mechanisms can be described as two mechanisms: increased metabolic detoxification (by detoxification enzymes) and target site modifications that lower their affinity for the considered insecticides (mutations of the voltage-dependent sodium channel, acetylcholinesterase, and GABA receptor genes) (9). Specific base changes at one or a few positions of the target DNA region explain the resistance to various insecticide groups (organochlorines, pyrethroids (PY), organophosphates (OPs), carbamates). Organochlorines and PY target voltage-dependent sodium channels, and OPs and carbamate target acetylcholinesterase (AChE). AChE is an enzyme that catalyzes the hydrolysis of acetylcholine and is a key enzyme in the insect nervous system for transmission (10). Biochemical studies revealed that insensitive acetylcholinesterase (iAChE), which targets the site of organophosphate (OP) and carbamate insecticides, causes insecticide resistance in many mosquito species. Insensitive AChE forms have been detected in mosquito species, such as Aedes albopictus, Anopheles gambiae, An. sacharovi and Culex pipiens, in many areas (11-13).

Although the development of resistance to chemical insecticides has been reported by different authors, chemical insecticides are still being heavily used in control operations in many areas of Turkey $(8,11,14-16)$. Ramsdale et al. (16) had reported carbamate and OP resistance in An. sacharovi populations from different regions in Turkey. Kasap et al. $(15,17)$ had described organochlorine, carbamate, $\mathrm{OP}$, and $\mathrm{PY}$ resistance in An. sacharovi, Culex tritaeniorhyncus, and Aedes caspius. Akiner et al. (18) had described organochlorine, OP, and PY resistance in $C x$. pipiens. They reported OP, organochlorine, and PY resistance of Thrace An. maculipennis populations (8).

However, all of the aforementioned studies identified resistance; there are few studies that focused on biochemical mechanisms of insecticide resistance $(8,11,19)$. They indicated that DDT

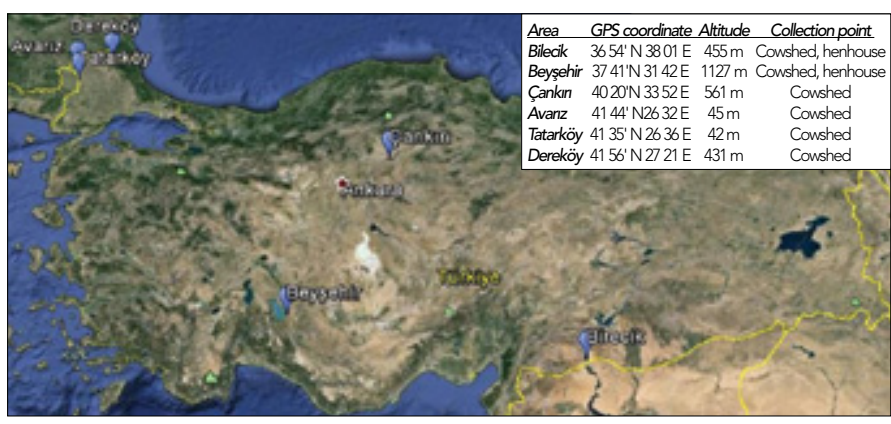

Figure 1. Location and brief description of collected populations

resistance may be related to DDT dehydrochlorinase activity in different populations of An. maculipennis species, Cx. tritaeniorhynchus, and Ae. caspius. Luleyap and Kasap (19) had reported that AChE, GST, and non-specific esterase activity levels were higher in the resistant group than in the susceptible groups. Akıner et al. (8) had reported increasing activity levels of nonspecific esterases, mixed fonction oxidases, and glutathione $\mathrm{S}$ transferases for An. maculipennis populations of the Thrace region in Turkey. Insecticide resistance status, related to AChE, has not been reported in resistance studies except for Luleyap and Kasap (19). Therefore, the objective of this study was to evaluate resistance related to $A C h E$ sensitivity and annual changes of AChE and insensitive AChE profiles in An. maculipennis from six different populations of Turkey.

\section{METHODS}

\section{Populations of An. maculipennis}

The study site's locations, GPS coordinates, and a brief description of the localities are provided in Figure 1. Larvae and adult samples of An. maculipennis were collected from six different localities in different regions of Turkey. Adult samples were collected by mouth aspirator and transferred to the laboratory alive inside net cages. We especially chose rice, cotton, and vegetable production areas for larval collection. Samplings were performed by dipping with a standard $400 \mathrm{~mL}$ dipper. All larval samples were transferred to the laboratory alive in plastic bottles. All tests were carried out with F1 generation adults or growing adult samples from collected larvae in the laboratory. All test samples were transferred to a $-80^{\circ} \mathrm{C}$ freezer until the date of biochemical analysis.

\section{Adult Bioassay}

Unfed adult female mosquitoes were assayed for susceptibility by diagnostic tests (20). Susceptibility was determined against malathion (5\%) and propoxur (0.1\%). One diagnostic concentration was used, and a 1-h application period was applied for malathion, while a 2-h application period was applied for propoxur. Mortality was recorded after a $24-\mathrm{h}$ rest- 
Table 1. Percentage mortality of Anopheles $v$ adults from six different areas exposed to diagnostic doses of malathion and propoxur in 2007 and 2008

\begin{tabular}{|l|c|c|c|c|c|c|c|c|}
\hline & \multicolumn{4}{|c|}{ Malathion 5\% } & \multicolumn{4}{c|}{ Propoxur 0.1\% } \\
\hline Strains & \multicolumn{2}{|c|}{$\mathbf{2 0 0 7}$} & \multicolumn{2}{c|}{$\mathbf{2 0 0 8}$} & \multicolumn{2}{c|}{$\mathbf{2 0 0 7}$} & \multicolumn{2}{c|}{$\mathbf{2 0 0 8}$} \\
\hline & No of Dead & \% Dead & No of Dead & \% Dead & No of Dead & \% Dead & No of Dead & \% Dead \\
\hline Birecik & 110 & 91.66 & 90 & 75 & 110 & 91.66 & 88 & 73.33 \\
\hline Beyşehir & 108 & 90 & 93 & 77.5 & 114 & 95 & 85 & 70.83 \\
\hline Çankırı & 111 & 92.5 & 94 & 78.33 & 118 & 98.33 & 94 & 78.33 \\
\hline Avarız & 105 & 87.5 & 98 & 81.66 & 102 & 85 & 100 & 83.33 \\
\hline Tatarköy & 107 & 89.16 & 99 & 82.5 & 100 & 83.33 & 98 & 81.66 \\
\hline Dereköy & 106 & 88.33 & 101 & 84.16 & 108 & 90 & 102 & 85 \\
\hline Note: Experiments were performed using 2 replicates, and each replicate contained 60 female mosquitoes & \\
\hline
\end{tabular}

ing period. Insecticide resistance status was evaluated by using the classification determined by WHO (21), in which 98\%-100\% mortality indicates susceptibility, 80\%-97\% mortality suggests possible resistance requiring confirmation, and $<80 \%$ mortality suggests resistance. A total of 2880 (1440 in 2007,1440 in 2008) adult females were analyzed from six localities for each insecticide (120 adult mosquito samples for each locality and year).

\section{Biochemical Assay}

Acetylcholinestease and insensitive AChE levels were measured individually in the adult females as described by WHO for possible iAChE (22). Standard flat-bottom microtiter plates (Nunch maxisorp ${ }^{\circledR}$, Nunch A/S, Roskilde, Denmark) were used for tests, and absorbance was read spectrophotometrically with an ELISA reader (Power Wave ${ }^{\circledR}$ XS, Biotek Instruments USA).

Biochemical analyses for individual mosquitoes were performed with two replicates of the homogenate. A total of 720 (360 in 2007, 360 in 2008) adult females were analyzed from six localities (60 adult mosquito samples for each locality and year).

Each An. maculipennis specimen was homogenized on ice in 200 $\mu \mathrm{L}$ of $50 \mathrm{mM}$ sodium phosphate buffer, $\mathrm{pH} 7.2$, and the homogenate was centrifuged at $10,000 \times \mathrm{g}$ for $10 \mathrm{~min}$ at $+4^{\circ} \mathrm{C}$. The supernatant was used as the source of enzymes. Total protein amount in $10 \mu \mathrm{L}$ of supernatant was measured using the Bradford assay in order to calculate the enzyme activity for each sample (23). Then, $300 \mu \mathrm{L}$ of Bradford dye reagent was added to each replicate, and the endpoint absorbance was read at $595 \mathrm{~nm}$. Protein values were calculated using a standard curve of absorbance of bovine serum albumin.

Two $25 \mu \mathrm{L}$ replicates of the supernatant were transferred to the microtiter plate for AChE and iAChE assays; $145 \mu \mathrm{l}$ of $1 \%$ triton phosphate buffer ( $\mathrm{pH}$ 7.8) was added each well, and $10 \mu \mathrm{l}$ of DTNB solution was added to each well. Then, $0.02 \mathrm{gr}$ acetylcholine iodide (ASCHI) was dissolved $5 \mathrm{ml}$ of water and divide in a half another container, and $5 \mu \mathrm{l}$ of propoxur was added to that half. $\mathrm{ACH}$ solution without propoxur added the first line. ASCHI solution with propoxur added the second line. Same procedure applied the 3 and 4 . lines. The final concentration of the final volume was read at $405 \mathrm{~nm}$ at the endpoint for the starting time and after a 1-hour incubation period at room tem- perature. The rate of inhibition calculated with and without propoxur well ODs.

\section{Statistical analysis}

Mean acetylcholinesterase inhibition values analyzed were compared between populations and years by the Kruskal-Wallis test and interpreted with box plot graphics.

\section{RESULTS}

\section{Bioassay}

In total, 2880 mosquitoes were analyzed for diagnostic tests. The results of the diagnostic tests are shown in Table 1. According to the diagnostic tests, all populations were placed in the surveillance category for malathion in 2007 (87.5\%-92.5\%). Mortality rates were decreased from 2007 to 2008 in all of the tested populations and went below 85\%. Although Thrace populations (Avarız, Tatarköy, Dereköy) were placed in the surveillance category in 2008, other populations (Birecik, Beyşehir, Çankırı) were placed in the resistant category. At the same time, Thrace populations mortality rates were closer to the resistant category (under 80\%) in 2008 (Table 1). Propoxur mortality rates varied between $83.33 \%$ (Tatarköy) to $98.33 \%$ (Çankırı). Mortality rates decreased from 2007 to 2008 in all of the tested populations but the Thrace region (Avarı, Tatarköy, Dereköy) change in the mortality rates of the populations was lower than that of the other tested strains. Although mortality rates decreased from 2007 to 2008, Avarız, Tatarköy, and Dereköy populations were placed in the surveillance category for propoxur. The other populations (Birecik, Beyşehir, Çankırı) were determined to be in the resistant category in 2008, and the highest decreasing rate was found in the Beyşehir population. (Table 1)

\section{Biochemical analysis}

In total, 720 field-collected offspring mosquitoe samples from six localities were analyzed for AChE and insensitive AChE. Propoxur inhibition rates are shown in Table 1. Mean inhibition rates varied between 34.12\% (Dereköy) to 89.69\% (Birecik) in 2007. In 2008, mean inhibition rates decreased in all of the tested populations and varied between $33.58 \%$ (Tatarköy) to $51.89 \%$ (Çankırı). All of the tested populations' inhibition rates decreased from 2007 to 2008 except Dereköy. In spite of the Inhibition rates decreasing around 40\%-45\% for Birecik Beyşehir and Çankiri, the Avarız and Tatarköy inhibition rates decreased around 10\%-20\% (Table 2, Figure 2). 
Table 2. Mean acetylcholinesterase inhibition rates of Anopheles maculipennis adults from six different areas in 2007 and 2008

\begin{tabular}{|l|c|c|c|c|}
\hline & \multicolumn{2}{|c|}{ Mean } & \multicolumn{2}{c|}{ Kruskal-Wallis test } \\
\hline Strains & $\mathbf{2 0 0 7}$ & $\mathbf{2 0 0 8}$ & $\mathbf{h}$ & $\mathbf{p}$ \\
\hline Avariz & $40.17 \pm 2.10$ & $36.63 \pm 2.43$ & 2.38 & 0.12 \\
\hline Tatarköy & $40.86 \pm 2.61$ & $33.58 \pm 1.96$ & 4.82 & 0.02 \\
\hline Dereköy & $34.12 \pm 2.07$ & $44.34 \pm 2.41$ & 9.46 & 0.002 \\
\hline Birecik & $89.69 \pm 0.57$ & $48.86 \pm 2.93$ & 84.75 & 0.0000003 \\
\hline Beyşehir & $84.71 \pm 1.34$ & $51.53 \pm 2.65$ & 60.34 & 0.0000007 \\
\hline Çankırı & $83.67 \pm 0.92$ & $51.89 \pm 2.59$ & 59.69 & 0.0000001 \\
\hline
\end{tabular}

\section{DISCUSSION}

Acetylcholinestease is a major molecular target for organophosphorus and carbamate insecticides, which inhibit the enzyme. In many insects, iAChE causes an important target site resistance mechanism to OP and carbamate insecticides (24). The present investigation has revealed suspected resistance status to malathion and propoxur in 2007. In 2008, mortality rates decreased, and some populations were placed into the resistant category according to the WHO (21). The others were placed in the stillsuspected-resistance status, but mortality rates were closer to the resistance border.

According to the biochemical tests, all of the tested populations exhibited sensitivity to propoxur inhibition. The Beyşehir, Çankırı, and Birecik population sensitivity to propoxur was high in 2007, but in 2008, the sensitivity decreased nearly 30\%-40\%. Although these populations showed a homogeneous structure for AChE sensitivity and inhibition rates in 2007, in 2008, they showed a heterogeneous structure (Figure 2). Malathion and propoxur diagnostic test results showed the same situation. Mortality rates decreased and reached nearly $70 \%-78 \%$ for malathion and propoxur in 2008 for these populations. The Avarız, Tatarköy, and Dereköy populations displayed heterogeneous structures for 2 testing years, but inhibition rates decreased (except Dereköy) from 2007 to 2008, like the other populations. In spite of increasing sensitivity for Dereköy, mortality rates for malathion and propoxur decreased from 2007 to 2008 . OP and carbamate resistance has described many mosquito species around the world, such as Cx. pipiens, Cx. quinquefasciatus, An. sacharovi, An. gambiae, and $C x$. tritaeniorhyncus $(11,13,25-27)$. Hemingway et al. (11) described sensitivity to inhibition to malaoxon and propoxur for the An. sacharovi Adana population. Less sensitive to insecticide inhibition, changed AChEs have been reported in the Culex genus in many areas $(25,28-30)$. Our study revealed that all tested populations had more or less insensitive AChE forms. Mortality rates and AChE sensitivity decreased for all strains from 2007 to 2008 . This situation may be related to the insecticide usage profile but not directly for mosquito control operations. OPs and carbamates are usually vegetable or fruit production areas and a small amount of mosquito control in Turkey. Malathion was used for mosquito control in the 1980s, and after, the usage of these insecticides was decreased for mosquito control by operators. Individual usage of these insecticides still continues indoors as hand spray or pressurized spray. The carbamate group insecticide usage situation has displayed

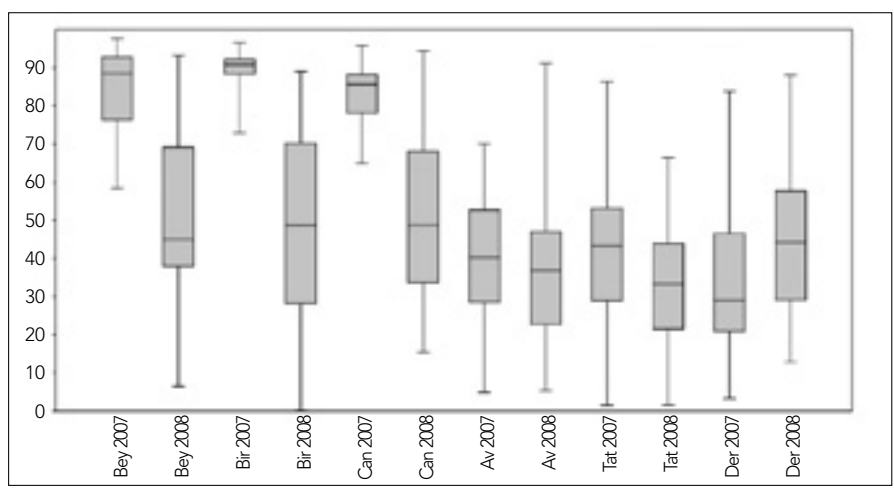

Figure 2. Acetylcholinesterase inhibition rates results from the localities evaluated

the same trend since the 1980s in Turkey. All collection sites were situated near agricultural areas, and larvae samples were collected from irrigation water ponds in the rice field (Avarız, Tatarköy, Çankırı), cotton (Birecik), and vegetable production (Beyşehir, Dereköy) areas. Insecticide resistance conferred by the iAChE form and cofactors have been reported in different mosquito strains due to selection pressure as a result of the extensive use of OPs and carbamate insecticides for mosquito control and pest control in agriculture $(8,14,19,31)$. Our results showed a similar situation and selection pressure as a result of the extensive use of OPs and carbamate for pest control in agriculture-a key factor for the malathion and propoxur resistance in all tested populations. Other biochemical mechanisms may act more or less on the OPs and carbamate resistance in all strains. Akıner et al. (8) reported increased NSE and GST enzymatic activity for different An. maculipennis in the Thrace region of Turkey. Some authors had reported that esterases play an important role in OP, carbamate, and PY resistance, and besides this, GSTs can provide resistance to these insecticides $(12,13)$.

\section{CONCLUSION}

Understanding resistance and mechanisms can be a guide to mosquito control. In this study, all the collection points were located at important agricultural areas in Turkey. The main occupation of the residents in these areas is rice, cotton, and vegetable cultivation, and residents suffer extremely from the mosquito problem. As a result of this situation, residents are using high amounts of agricultural insecticides and commercial hand sprays for mosquito control. More detailed studies that understand the biochemical mechanisms and molecular basis of the resistance are needed to establish effective mosquito control strategies and to arrest possible mosquito-borne disease epidemics for these areas.

Ethics Committee Approval: Ethics committee approval was not received due to the retrospective nature of this study.

Peer-review: Externally peer-reviewed.

Author Contributions: Concept - M.M.A.; Design - M.M.A.; Supervision - M.M.A.; Funding - M.M.A.; Materials - M.M.A.; Data Collection and/or Processing - M.M.A.; Analysis and/or Interpretation - M.M.A.; Literature Review - M.M.A.; Writing M.M.A.; Critical Review - M.M.A.; Other - M.M.A. 
Conflict of Interest: No conflict of interest was declared by the authors.

Financial Disclosure: The authors declared that this study has received no financial support.

Etik Komite Onayı: Çalışmamızın retrospektif tasarımından dolayı etik komite onayı alınmamıştır.

Hakem Değerlendirmesi: Dış bağımsız.

Yazar Katkıları: Fikir - M.M.A.; Tasarım - M.M.A.; Denetleme M.M.A.; Kaynaklar - M.M.A.; Malzemeler - M.M.A.; Veri toplanması ve/veya işlemesi - M.M.A.; Analiz ve/veya yorum - M.M.A.; Literatür taraması - M.M.A.; Yazıyı yazan M.M.A.; Eleştirel inceleme - M.M.A. ; Diğer - M.M.A.

Çıkar Çatışması: Yazarlar çıkar çatışması bildirmemişlerdir.

Finansal Destek: Yazarlar bu çalışma için finansal destek almadıklarını beyan etmişlerdir.

\section{REFERENCES}

1. Akıner MM. Sivrineklerde direnç tespiti ve direnç gelişimini sağlayan enzimatik mekanizmaların araştırılması. Doktora Tezi, Hacettepe Üniversitesi Fen Bilimleri Enstitüsü; 2009.

2. Akıner MM, Simsek FM, Caglar. Insecticide resistance of Culex pipiens (Diptera: Culicidae) in Turkey. J Pestic Sci 2009; 34: 259-64. [CrossRef]

3. Akıner MM, Caglar SS, Simsek FM. Yearly changes of insecticide susceptibility and possible insecticide resistance mechanisms of Anopheles maculipennis Meigen (Diptera: Culicidae) in Turkey. Acta Trop 2013; 126: 280-5. [CrossRef]

4. Becker N, Petric D, Zgomba M, Boase C, Dahl C, Lane J, Kaiser A. Mosquitoes and their control. Kluwer Academic, Plenum publishers; 2003. [CrossRef]

5. Bourguet D, Capela R, Raymond M. An insensitive actylcholinesterase in Culex pipiens (Diptera: Culicidae) from Portugal. J Econ Entomol 1996; 89: 1060-6.

6. Bradford MM. A rapid and sensitive method for the quantitation of microgram quantities of protein utilizing the principle of protein-dye binding. Anal Biochem 1976; 72: 248-54. [CrossRef]

7. Bruce-Chwatt $L$, de Zulueta J. The rise and fall of malaria in Europe. A-historico-epidemiological study, Oxford: University Press; 1980

8. Corbett JR. The biochemical mode of action of pesticides. London: Academic Press; 1974.

9. Cui F, Raymond M, Berthomieu A, Alout H, Weill M, Qiao CL. Recent emergence of insensitive acetylcholinesterase in Chinese populations of the mosquito Culex pipiens (Diptera: Culicidae). J Med Entomol 2006; 43: 878-83. [CrossRef]

10. Etang J, Manga L, Toto JC, Guillet P, Fondjo E, Chandre F. Spectrum of metabolic-based resistance to DDT and pyrethroids in Anopheles gambiae s.l. populations from Cameroon. J Vector Ecol 2007; 32: 123-33. [CrossRef]

11. Hemingway J, Malcolm CA, Kissoon KE, Boddington RG, Curtis CF, Hill N. The biochemistry of insecticide resistance in An. sacharovi: Comparative studies with a range of insecticide susceptible and resistance Anopheles and Culex species. Pesticide Biochem and Physiol 1985; 24: 68-76. [CrossRef]

12. Hemingway J, Ranson $\mathrm{H}$. Insecticide resistance in insect vector of human disease. Ann Rev Entomol 2000; 45: 375-91. [CrossRef]

13. Hemingway J, Hawkes NJ, McCarroll L, Ranson H. The molecular basis of insecticide resistance in mosquitoes. Insect Biochem Mol Biol 2004; 34: 653-65. [CrossRef]
14. Jetten TH, Takken W. Anophelism without malaria in Europe -a review of the ecology and distribution of the genus Anopheles in Europe. Wageningen Agricultural University Papers 1994; 94-5.

15. Kasap $H$, Luleyap U, Alptekin D, Kasap M. Use of insecticides in Cukurova and development of resistance in mosquitoes. Acta Par Turcica 1999; 23: 267-72.

16. Kasap H, Kasap M, Alptekin D, Luleyap U, Herath PR. Insecticide resistance in Anopheles sacharovi Favre in southern Turkey. Bull World Health Organ 2000; 78: 687-92.

17. Linton YM, Smith L, Harbach RE. Molecular confirmation of sympatric populations of Anopheles messeae and Anopheles atroparvus overwintering in Kent, southeast England. European Mosq. Bull 2002; 13: 8-16.

18. Luleyap $U$, Kasap $H$. Insecticide resistance in malaria vector An. sacharovi. Turk J Biol 2000; 24: 437-60.

19. Mayima A, Ishikava $Y$, Kono Y. Actylcholinesterase in insecticide resistant Culex tritaeniorhyncus: characteristics accompanying insensitive to inhibitors. App Entomol Zool 1997; 32: 37-44.

20. Nebeshima T, Mori A, Kozaki T, Iwata Y, Hidoh O, Harada S, et al. An amino acid sustititon attribute to insecticide-insensitivity of acetylcholinesterase in a Japanese encephalitis vector mosquito, Culex tritaeniorhyncus. Biochem Biophys Res Commun 2004; 313: 794-801. [CrossRef]

21. Ramsdale CD, Herath $P$, Davidson G. Recent developments of insecticide resistance in some Turkish anophelines. J Trop Med and Hyg 1980; 83: 11-9.

22. Ramsdale CD, Alten B, Çaglar SS, Ozer N. A revised, annotated checklist of the mosquitoes (Diptera: Culicidae) of Turkey. Euro Mosq Bull 2001; 9: 18-28.

23. Raymond M, Fournier D, Bride JM, Cuany A, Berge J, Magnin M, et al. Identification of resistance mechanisms in Culex pipiens (Diptera: Culicidae) from southern France: insensitive acetylcholinesterase and detoxifying oxidases. J Econ Entomol 1986; 79: 1452-8.

24. Sedaghat MM, Linton YM, Nicolescu G, Smith L, Koliopoulos G, Zounos AK, et al. Morphological and molecular characterization of Anopheles (Anopheles) sacharovi Favre, a primary vector of malaria in the Middle East. Syst Entomol 2003; 28: 241-56. [CrossRef]

25. Simsek FM, Ulger C, Akiner MM, Tuncay SS, Kiremit F, Bardakci F. Molecular identification and distribution of Anopheles maculipennis complex in the Mediterranean region of Turkey. Biochem System and Ecol 2011; 39: 258-65. [CrossRef]

26. Tantley ML, Tortosa P, Alout H, Berticat C, Berthomieu A, Rutee A, et al. Insecticide resistance in Culex pipiens quinquefasciatus and Aedes albopictus mosquitoes from La Réunion Island. Insect Biochem Mol Biol 2010; 40: 317-24. [CrossRef]

27. Toutant JP. Insect acetylcholinesterase: catalytic properties, tissue distribution and molecular forms. Progr Neurobiol 1989; 32: 423-46. [CrossRef]

28. Weill M, Lutfalla G, Mogensen K, Chandre F, Berthomieu A, Berticat $C$, et al. Comparative genomics: Insecticide resistance in mosquito vectors. Nature 2003; 423: 136-7. [CrossRef]

29. Weill M, Malcolm C, Chandre F, Mogensen K, Berthomieu A, Marquine $M$, et al. The unique mutation in ace-1 giving high insecticide resistance is easily detectable in mosquito vectors. Insect Mol Biol 2004; 13: 1-7. [CrossRef]

30. WHO (World Health Organization). Instructions for determining the susceptibility or resistance of adult mosquito to organochlorine, organophosphate and carbamate insecticides-diagnostic tests. 1981; WHO/NBC/81.806.

31. WHO (World Health Organization), Techniques to detect insecticide resistance mechanisms (field and laboratory manual). 1998; WHO/ CDS/CPC/MAL/98.6 